Д-р екон. наук О.Г. Дейнека,

О.В. Кармаш

\title{
ПІДХОДИ ДО ОЦІНКИ ЕКОНОМІЧНОЇ ЕФЕКТИВНОСТІ НОВИХ ФОРМ ТРАНСПОРТНОГО ОБСЛУГОВУВАННЯ НА ОСНОВІ ІННОВАЦІЙНОЇ ДІЯЛЬНОСТІ
}

Постановка проблеми. Інноваційний шлях розвитку нашої країни $є$ головним пріоритетом економічної політики в даний час. Інновації як основа стратегії розвитку підприємства включають не тільки технічні й технологічні розробки, а й пошук $\mathrm{i}$ використання нових форм бізнесу, нових методів роботи на ринку, нових товарів i послуг. Вони характеризуються більш високим технологічним рівнем, більш високими споживчими якостями в порівнянні з попереднім продуктом.

Оцінка економічної ефективності нових форм і методів обслуговування клієнтів сприяє забезпеченню стійкої динаміки економічного зростання підприємницьких, фінансових, кредитних, будь-яких інших структур за рахунок пропозиції конкурентоспроможних послуг. Оцінка економічної ефективності має першорядне значення для розвитку транспортного бізнесу, підвищення ефективності його функціонування на перспективу, залучення нових клієнтів, збільшення обсягів перевезень за рахунок залучення їх 3 конкурентних видів транспорту, операторських i експедиторських компаній.

У зв'язку 3 реформуванням залізничного транспорту, створенням експедиторських організацій різко зросла конкуренція як всередині залізничного транспорту, так і між іншими видами транспорту. Тому вже не достатньо чекати, коли клієнт прийде сам, а необхідно зосередити увагу на пошуці нових рішень i конкретних шляхів, спрямованих на формування ефективних взаємовідносин 3 користувачами послуг залізничного транспорту.

Залізничний транспорт, об'єднуючи в єдиний комплекс багато галузей країни, повинен проводити ефективну інноваційну політику. При цьому слід враховувати, що залізничний транспорт протягом всієї історії свого розвитку є однією з найбільш наукоємних галузей економіки. Основне завдання інноваційної політики на транспорті - розроблення і впровадження науково-технічних досягнень, які дозволили б вивести залізничний транспорт на якісно новий рівень розвитку.

Аналіз останніх досліджень i публікацій. Управління інноваціями розглядається останнім часом як важлива складова теорії і практики управління, привертає увагу багатьох вітчизняних i зарубіжних дослідників.

Теоретичні та практичні питання управління інноваціями докладно розглядаються в працях таких зарубіжних вчених як Шумпетер I., Санто Б., Твісс Б., Фрідмена Х., Ніксона Ф. та ін.

Проблеми оцінки ефективності інноваційних та інвестиційних проектів відображені в працях Трифілова А.А., Трихункова М.Ф., Волкова Б.А., Кошкарова С.В.

Питання управління якістю транспортного обслуговування клієнтури i сервісної діяльності на транспорті знайшли відображення у працях Абрамова А.П., Галабурди В.Г., Громова М.М., Журавля А.І., Комарова О.В., Лівшиця В.Н., Трихункова М.Ф., Царьова Р.М., Лапідуса Б.М., Ніколашина В.М., Іванкова Л.М., 
Іванкової О.М., Іловайського Н.Д., Кисельова О.М. та ін.

Серед зарубіжних праць з маркетингу послуг можна відзначити праці Д. Маккарті, М. Бітнера, Ф. Котлера, К. Гренроса, П. Ейгліе і Е. Лангеарда та ін. Разом 3 тим, у науковій та методичній літературі висвітлюються окремі аспекти теорії і практики інновацій, але недостатньо досліджена i розроблена проблема управління інноваціями на транспорті, зокрема в галузі обслуговування клієнтів.

Виділення невирішених частин загальної проблеми. Основну увагу в даній статті приділено економічній оцінці інноваційної діяльності в соціальноекономічних системах, зокрема в системі взаємовідносин 3 клієнтами на українських залізницях, економічній оцінці впроваджених інновацій в обслуговування кліснтів та розробленню практичних рекомендацій щодо поліпшення інноваційного клімату в галузі обслуговування клієнтів.

Ми вважаємо, що існуючий рівень обслуговування клієнтів українськими залізницями недостатній, у зв'язку 3 чим, частина клієнтів відмовляється від перевезень залізничним транспортом i переходить на конкурентні види транспорту або звертається в операторські й експедиторські компанії.

Таким чином, актуальність даної статті визначається вимогами сьогоднішнього стану економіки країни, при якому інноваційна політика повинна сприяти розвитку науково-технічного потенціалу, підвищенню якості й конкурентоспроможності продукції, та потребами забезпечення економічного зростання, розширенням транспортноекономічних зв'язків країни з економічно розвиненими державами, 3 урахуванням конкуренції між залізничним та іншими видами транспорту.

Формування цілей статті. Метою даної статті $\epsilon$ розроблення теоретичних підходів до оцінки економічної ефективності нових форм i методів обслуговування клієнтів на основі інноваційної діяльності.

Виклад основного матеріалу дослідження та обгрунтовування одержаних наукових результатів. Світовий досвід показує, що забезпечення стійкості фінансово-економічного становища сучасних компаній багато в чому визначається інноваційним характером виробництва. При цьому оцінка ефективності інновацій $\epsilon$ центральною ланкою в процесі економічного розвитку компаніі. Ефективність інноваційного проекту відображає відповідність проекту цілям та інтересам його учасників.

Для того, щоб вивчити комплексний характер інновацій, розкрити різноманітні галузі їх використання i різні методи управління, необхідно розглянути класифікацію інновацій. При цьому слід враховувати, що огляд класифікацій інновацій грунтується на двох підходах: виробничо-технологічному i функціонально-спеціалізованому, при цьому в існуючих класифікаціях не розглядаються інновації за умовою економічної ефективності. Ми вважаємо, що найбільш повною є така класифікація, в якій інновації розглядаються за ознаками економічної ефективності, ступенем ризику, цільовими змінами, масштабами викликаних наслідків.

Інновації у сфері обслуговування являють собою процес оновлення всіх сторін роботи 3 клієнтами, орієнтації співробітників на пошук оригінальних шляхів взаємодії 3 клієнтами. Пошук ефективних форм управління інноваціями пов'язаний $з$ виділенням і відокремленням підрозділів, що займаються інноваціями і довгостроковими проблемами розвитку компанії, а також з необхідністю створення механізму інтеграції та координації діяльності, взаємодії в ході розроблення та впровадження інновацій. 
На розроблення цілей інноваційної політики, іiі принципів, а також механізмів реалізації впливає державне регулювання. Основою інноваційної політики України $є$ формування та розвиток національної інноваційної системи, яка являє собою сукупність взаємодіючих суб'єктів державного та приватного секторів економіки.

Активізація інноваційної діяльності вимагає, 3 одного боку, державного управління та координації дій всіх iï суб'єктів, 3 іншого - інтеграції всіх зацікавлених структур у реалізації інновацій, залученні інвестицій, створенні умов, що сприяють інноваційному процессу, та впровадженні досягнень науки і техніки в економіку країни.

Досвід зарубіжних компаній, що успішно розвиваються, показує, що сьогодні виживає той, хто вміє швидко реагувати на зміни і впроваджує інновації в компаніях. Механізм формування та реалізації інноваційної політики за кордоном різний, проте подібні закономірності розвитку виробництва та підходи до інноваційної діяльності: наявність ефективної системи маркетингу і збуту, що здійснює зв'язок підприємства 3 кінцевим споживачем; всебічний облік потреб клієнта при найвищому рівні надійності виконання взятих зобов'язань; зростання витрат на наукові дослідження і розробки, основне джерело фінансування при цьому - власні кошти підприємства, державні цільові програми та фонди, фонди приватних інвесторів.

Таким чином, інноваційний прорив для сучасної України являє собою реальну складову швидкої модернізації країни, шлях підвищення соціально-економічного розвитку суспільства. Причому аналіз сучасного ринку показує, що поряд 3 такими чинниками, стримуючими процеси розроблення та впровадження інновацій, як фінансові та інформаційні, можна виділити такі: недостатній розвиток законодавства в галузі інноваційної діяльності; дефіцит фахівців в галузі розроблення i впровадження нових технологій, продуктів у ринкових умовах; відсутність ефективних методик залучення нових технологій $\mathrm{y}$ господарський обіг; низька якість інноваційного менеджменту (висока питома вага керівників, які не бачать необхідності в інноваційній діяльності).

Ефективна інноваційна політика $\epsilon$ одним з інструментів залучення додаткових обсягів перевезень і збільшення доходів залізниці.

Загальна концепція формування інноваційної політики на транспорті розглядається в роботі з таких позицій:

- збалансована інноваційна політика та створення системи управління інноваціями $\epsilon$ одними 3 найважливіших умов забезпечення ефективної та стійкої роботи залізниць;

- фінансове забезпечення інноваційної діяльності має грунтуватися на його цільовій орієнтації і множинності джерел фінансування;

- рівень якості обслуговування, гнучке реагування на запити клієнтів, гнучка тарифна політика $\epsilon$ найважливішими показниками конкурентоспроможності того чи іншого виду транспорту, інструментом для завоювання ринку;

- підвищення якості транспортного обслуговування вимагає переходу від гострої конкуренції до співпраці з іншими видами транспорту. Необхідне розроблення моделі співпраці 3 іншими видами транспорту для забезпечення комплексного обслуговування клієнтів, надання можливості інтермодальних перевезень;

- необхідне розроблення технології обслуговування різних груп клієнтів, підпорядкування інтересів транспорту інтересам клієнтів, що $є$ взаємовигідним для обох сторін.

Слід зазначити, що на транспортному ринку постійно розширюється спектр послуг для клієнтів, що працюють за принципом «одного вікна»; впровадження оптимальних транспортних схем 
доставлення вантажів, доставлення «від дверей до дверей» i «точно в строк»; організація контрейлерних, інтермодальних перевезень, єдині технології на напрямках, що прилягають до прикордонних переходів, морських портів, а також до великих вантажовідправників та вантажоодержувачів; взаємодія 3 компаніями-операторами; контейнеризація перевезень, тобто побудова обслуговування на логістичних принципах.

Необхідно відзначити важливу роль інформаційного обслуговування в інноваційному процесі - нині електронізація стала для залізничного транспорту бізнествірним чинником, однією 3 умов успішного реформування галузі. В аспекті якості транспортного обслуговування інформаційні технології забезпечують контроль всіх аспектів взаємин 3 конкретним користувачем послуг залізничного транспорту: платоспроможність клієнта, наявність договорів на перевезення, відсутність заборон на переміщення даного виду вантажу.

На різних етапах підготовки та ухвалення управлінських рішень, пов'язаних 3 інноваційною діяльністю на підприємстві, необхідно прогнозувати дохід від впровадження нових технологій, напрямків, програм, проектів, тобто виникає необхідність економічної оцінки інновацій. Кінцева мета - відбір технологій, здатних зробити внесок у прогресивні технологічні зрушення на залізничному транспорті, що забезпечують істотне підвищення його роботи.

Висновки даного дослідження i перспективи подальших робіт у вказаному напрямі. У процесі підготовки цієї статті виявлено, що активізація інноваційної діяльності сприятиме вирішенню таких актуальних соціальноекономічних проблем, як: модернізація виробничих комплексів; підвищення конкурентоспроможності товарів і послуг на світових ринках; збереження та ефективне використання науковотехнічного й інноваційного потенціалів, залучення інвестицій; створення нових робочих місць.

Особливість реалізації інноваційних процесів в умовах реструктуризації на транспорті полягає в необхідності розроблення організаційно-економічного механізму стратегічного партнерства 3 великими вантажовласниками, який би забезпечив збільшення обсягів перевезень, а також залучення нових клієнтів при збереженні наявної клієнтської бази.

Таким чином, необхідно сформувати систему обгрунтованих організаційноекономічних рішень, це надалі може сприяти підвищенню ефективності управління інноваційною діяльністю галузі залізничного транспорту.

\section{Список літератури}

1. Федулова, Л. Інноваційний розвиток економіки: модель, система управління, державна політика [Текст] / за ред. Л.Федулової. - К.: Основа, 2005. - 552 с.

2. Шарко, М. Модель формування національної інноваційної системи України [Текст] / М. Шарко // Економіка України. - 2005. - №8. - С. 25-30.

3. Економіка і організація інноваційної діяльності: підручник [Текст] / O.I. Волков, М.П. Денисенко, А.П. Гречан [та ін.]; за ред. проф. О.І. Волкова, проф. М.П. Денисенка. - К.: ВЦ «Професіонал», 2004. - 960 с.

4. Гаєць, В. Інноваційні перспективи України [Текст]: монографія / В. Геєць, В.Семіноженко. - Харків: Константа, 2006. - 272 с. 
Ключові слова: транспортне обслуговування, інноваційна діяльність, економічна ефективність перевезень, транспортні послуги.

\section{Анотаціï}

Стаття присвячена теоретичним і практичним аспектам організації транспортного облуговування на основі інноваційної діяльності. Розглянуто підходи до оцінки економічної ефективності нових форм і методів обслуговування клієнтів залізниць України.

Статья посвящена теоретическим и практическим аспектам организации транспортного облуживания на основе инновационной деятельности. Рассмотрены подходы к оценке экономической эффективности новых форм и способов обслуживания клиентов железных дорог Украины.

The article is devoted to theoretical and practical aspects of the organization of the transport tinning on the basis of innovation. The approaches to the assessment of the economic efficiency of new forms and methods of customer service of the Ukrainian railways. 